\title{
詩人アクバル・イラーハーバーディーとその詩 片岡弘次
}

1857年のインド大反乱は，イギリスによる植民地化の影響を受けていた，イン ド人の積年の不満の爆発であったが，ての大反乱の挫折は，ムガル朝の終りと， インド・ムスリムの衰退を決定的にするものであった。そしてインド・ムスリム はその攘夷的な姿勢の転換を余儀なくされたが，その中で新しい時代への転換を 自覚的に唱えたのが，サル・サィヤド・アフマッド・カーン (1817 98) であった。 サル・サィヤドは, 大反乱以降, 積極的にイギリス植民地行政に結びっき, 植民 地官僚に進出することを人々に訴え, そのためには, ムスリムが近代的教育を受 ける必要があると説いた。これは大反乱の敗北以後, 虚脱状態にあったムスリム 上流階級の間に大反響を呼び起し，それがアリーガル運動として発展した。

アリーガル運動の基本的立場は親英策であったが，その親英の意味は，被支配 者のムスリムが，イギリスに盲従するのでなく，ムスリムの上流階級あるいは新 中間階級がイギリスの近代的市民倫理を身に着け，その上で植民地支配者に対し 自分達の正当な権利を尊重させることであった。そのために近代的教育機関の設 立とそこでの教育の必要が起り, 偏狭さを排し, 理性至上主義の提唱が必要にな った。この運動の中で, ウルドゥー文学も, 社会的意味や改革的意味を殆ど持た なかった従来の文学から, 目的意識や功利的な意味を持つ文学に变り, アリーガ ル運動推進の一翼を荷うことになった。ハーリー(1837 1914), M・H・アーザ ード (1832 1910)，シブリー（1857１914），アクバル（1846１921）等は当時を代 表する詩人や作家で，それぞれ多少の違いはあるにしても，前三者は運動推進派 として，アクバルは批判的な立場を取りながら，19世紀末，ウルドゥ一文学を近 代文学へ転換させて行く原動力となった。

アクバルは1846年アラーハーバードのバーラーで生まれた。祖父はウラマー, 父親も信仰に厚く，父親からペルシャ語やアラビヤ語を学び，そして後に，アク バルがアリーガル運動に批判的立場を取る要因の一つとなった神秘主義の影響 も受けて育った。初等教育はアラーハーバードのミッション・スクールで受けた が，アラーハーバードがインド大反乱の中心的舞台の一つとなると，1859年，学 校が閉鎖され，僅か 3 年で学校を止めねばならなかった。学校を止めると初め, 


$$
\text { 詩人アクバル・イラーハーバーディーとその詩 (片 阙) }
$$

東インド会社の建設局で働いたが，それはアクバルに向かず，文学や詩の会が開 かれるとそれに出席し，法律や英語の勉強も始めた。その後，裁判所に勤め，判 決文のすべてが英語で書ける位，英語の運用力は増した。青年時代は自由奔放な 生活を送るが, 21 歳の時, 下級判事の試験に合格, 23 歳の時, 副徵税官となり, 27歳の時には，上級判事の試験に合格，ハイコートで判事となり，35歳で裁判官 となった。アクバルのとの順調な昇進は，インド大反乱以降，ムスリムが職を得 るのが難かしくなった中で，異例のことであった。即ち1857年の大反乱の処理に 対し，イギリス統治者の態度は，ヒンドゥーやシックに較べムスリムには重い刑 罰を科し，一般のムスリムは職に就けず，ムスリムを孤立させる分割策が取られ ていたからであった。

サル・サイヤドが1870年，イギリスから㷌国したのは，ムスリムがこの様な苦 境に陥っていた最中であった。サル・サィヤドはこの苦境打破のために，イギリ スとムスリムとの間にある見解の相違や䛊解を解こうと，西欧の学術や文明を取 り入れ，人々の間の意識の変革を求める改革を始めた。しかしとのサル・サィヤ ドの運動に対して，やがてアジアの精神と気質に反すると考える者が現われ，末 たイスラームに対し，懐疑と無関心さを起させたので， ウラマーはサル・サィヤ ドのとの啓蒙運動を宗教に対する危険なものと考えた。一方アジアの文化や慣習 に愛着克抱く者は，その伝統が失なわれたり，文化的背景が破猿されて行くのに 耐えられながった。アクバルはその後者であった。

アクバルが本格的に詩作活動を始めるのは30代の後半からであった。アクバル は諷刺詩人と言われるが，その詩には次の三つの外面的影響，即ちラクナウ詩 派からの影響，『アワド・パンチ』誌の影響，アリーガル運動からの影響があっ た。

アクバルの詩の特幑である諷刺やウイットは，ラクナウ詩派と『アワド・パン チ』誌からの影響が大きかった。アクバルは詩を初め，アーティシ（1785年前後 〜1846）の弟子，ワーヒドから習い，ラクナウ詩派の濃いガザルを書いた。ラク ナウ詩派のガザルにはウイットのためのウイットが多くあった。更にアクバルの 諷刺に手本在示したのは，1877年，アクバルが28嵅の時ラクナウから出され， 1912年まで続いたユーモアを主体にした『アワド・パンチ』誌であった。それは 近代化の風潮に反対し，アリーガル運動に批判的な雑誌で，アクバルは役人とい ら立場上，憶病な程，政治と正面から相刘することは避け，『アワド・パンチ』 式の書き方を取った。しかしアクバルの諷刺は程なく，その軽率で浮薄なものか 
詩人アクバル・イラーハーバーディーとその詩 (片 岡)

ら, 道徳的強靭さを持った諷刺へと変った。そしててのアクバルの詩の諷刺やウ イットの素材を与えたのは，アリーガル運動で，それ故サル・サィヤドなしには， アクバルの存在もなかったと言わなければならない。特に，1884年から 4 年間に 渡るアクバルのアリーガル滞在は, サル・サィヤドの運動を間近で見させ，アク バルに諷刺の鋭い矢を尖らす機会を与えた。それは，アクバルがリル・サィヤド の使命の偉大さを認識できなかった訳ではなく，そてには，社会的，政治的リー ダーとしての少ル・サィヤドの偉大さへの個人的羡望の気持も働いていた1)。

アクバルの諷刺には，乙れら外面的影響の他に，アクバルの中にあった神秘主 義的，モラリスト的，懐古主義的，禁欲主義的要素がある。これらの要素が，時 に単独で，時に幾つかが結合して現われる。

その神秘主義的要素は，年と共に，アクバルの精神的生活を覆いながら成長し， アクバルの批評精神の根幹となった。即ち, 新しいものを取り入れるのに忙し過 ぎるその運動は，人間生活の究極の目標である神との精神的結合を不可能にする ように見えた。またその運動に刘するアクバルの不信は, 人々の道徳的急変から でもあった。物質的目標を揭げてするそれは，退廃的なものにしか見えず，アク バルにとり進歩とは, 内的完成であり, 知識の習得ではなかった。理性を優先さ せ，すべてを理性で判断しょうとした当時の改良主義者に対し，アクバルは直感 を重んじた。それ故, 無駄なものを取り除とらとする改良主義者は, アクバルに は，イスラームへの攻撃としか見えなかった。アクバルにとり，過去は神聖で批 判することの出来ないもので, そしてその敬愛の対象は, 宗教だけに限らず，文 学, 着物, 教育などムスリムの過去のあらゆるものを含んでいた。

しかしての過去への強い執着は，アクバルの弱い所でもあった。アクバルは社 会の愚行や腐敗に対する深い洞察力があり，大胆に物質文明を批判したが，新し い社会や文化に対する極端度禁欲的な態度は, 新しいものから起ってくる美や理 想に対して，自からを盲目の人にしてしまう危険があった。更にそれに生来の陰

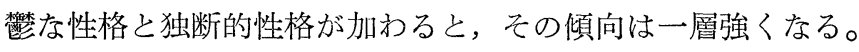

アクバルの詩は 19 世紀の 70 年代から 20 世紀の 20 年代まで，およそ半世紀に及ぶ インド・ムスリムの政治, 社会の写しであったが, その一番のテーマは, アリー ガル運動に際し，急激に流入して来た西洋文化の影響より生じた文化と社会の変 化に関してであった。即ち, 西洋かぶれした者が英語を得意がって話し，自己の 言葉を軽茂したり，新教育の影響で女性がパルダーを取ったり，ケイキやビスケ ットを食べ始めたり, 舶来の香水を匂わせたり, 或いはシガレットの煙りの中に, 
フッカーの煙りが消え入ってしまらてとは，アクバルには耐えられなかった。ア クバルにとり民族文化や社会の基礎はイスラームの宗教や道徳であったので, 物 質崇拝に基づく西洋文化が民族全体を覆ってしまらのでないか，イスラームの精 神的向上，倫理的価值は，どこかに追いやられてしまらのではないかと懸念した からであった。特に新教育は, 宗教の持つ重要な意義を強調する代りに, 宗教と 自然, 精神性と物質性のあいだの調和の努力を不明確にしていた点が，納得いか なかっだ2)。

更に，植民地主義に対するとともアクバルの重要なテーマであった。西洋文化 や社会の影響は，政治的支配の後に起って来る精神的支配と関係があると考えた からであった。この点，アクバルはイギリス帝国主義に反して聖戦の旗を揭げた 最初のウルドゥ一詩人と言える ${ }^{3)}$ 。

インド大反乱の終結はイギリスが植民地体制を完成し終った時であったが，そ れはインド・ムスリムの新教育で身を飾ったプロフェッサーが，植民地支配から 自らを解放させる努力を始めた時でもあった。そしてアクバルは大砲の代りに諷 刺の武器を取上げ，民族の苦痛や苦悩を心に秘め，新しい文化戦争を戦い始めた。 その詩には，新時代の新しい階層の人々や，片仮名混りの英語の語句まで含まれ， 新時代の人々への警告や覚醒となった。しかしての様な諷刺も，1921年に亡くな るまでの晚年の 10 年間は，アクバル自身の目の病気や，妻や子供の死で影を潜め， 代りに神秘主義的傾向が増した。アクバルを，当時の社会的要求や認識を欠いた 復古主義者と非難する人もいるが，その詩はムスリム解放運動の道案内となり， ムスリム復興を期したイクバール等に影響を与えるととになった。

1) “A HISTORY of URDU LITERATURE” Oxford University Press, 1964, p. 305.

2）『近代ウルドウ文学史研究』東海大学出版会, 昭和54年, p. 67.

3) “Urdū shā'irī ka siyāsī aur samājī pas manzar” Oriental College Lahore, 1966, p. 382 . 